\title{
Abundance and production of bacteria and viruses in the Bering and Chukchi Seas
}

\author{
Grieg F. Steward *, David C. Smith, Farooq Azam \\ Scripps Institution of Oceanography, University of California, San Diego, La Jolla, California 92093-0202, USA
}

\begin{abstract}
The distribution, abundance, and production of viruses and bacteria were investigated during an August to September 1992 cruise aboard the RV 'Alpha Helix' in the Bering and Chukchi Seas. Viruses were abundant in seawater samples at all stations $\left(10^{9}\right.$ to $\left.10^{10} \mathrm{l}^{-1}\right)$ and exceeded the bacteria concentration by an order of magnitude on average. Virus-like particles and bacteria were also observed in the pore water of a sediment sample at 27 and $2.1 \times 10^{9} \mathrm{l}^{-1}$, respectively. The concentrations of viruses and bacteria in pelagic samples were correlated $(r=0.83, n=43)$. In a detailed depth profile from the deepest and northernmost station $\left(72^{\circ} \mathrm{N}\right)$, bacteria and viruses displayed subsurface maxima in the upper $100 \mathrm{~m}$. Below $100 \mathrm{~m}$, the concentrations declined, but were detectable even in the deepestcollected samples $(402 \mathrm{~m})$. Integrated bacterial biomass estimates were similar to results from a previous study in this area, but bacterial production measurements ranging from 0.3 to $0.45 \mathrm{~g} \mathrm{C} \mathrm{m}^{-2} \mathrm{~d}^{-1}$ were an order of magnitude higher. Production rates of bacterial viruses (also known as bacteriophages or simply phages) measured by radiolabeling ranged from 0.5 to $4.2 \times 10^{9}$ viruses $\mathrm{l}^{-1} \mathrm{~d}^{-1}$, which are similar to previous estimates for temperate coastal waters. The production measurements indicated turnover times ranging from 0.4 to $17 \mathrm{~d}$ for bacteria and maximum estimates of 1.2 to $15 \mathrm{~d}$ for bacterial viruses. Viral mortality of bactena was estimated from the frequency of visibly infected cells (FVIC) and flagellate grazing was calculated from flagellate and bacterial abundances together with an assumed flagellate clearance rate. Overall, estimated viral lysis was roughly comparable to estimated grazing by flagellates as a source of bacterial mortality. Averaged over the water column, viral mortality of bacteria in the Chukchi Sea was estimated to be $23 \%$ of the bacterial production at 2 southern stations and approximately $10 \%$ at 2 northern stations. FVIC was correlated with bacterial production $(\mathrm{r}=0.75$, $\mathrm{n}=18)$ and specific growth rate $(\mathrm{r}=0.74, \mathrm{n}=18)$, but not with bacterial abundance $(\mathrm{r}=0.22, \mathrm{n}=27)$. These data suggest viruses to be a ubiquitous and dynamic feature and a significant source of bacterial mortality in Arctic marine microbial communities. The implications of bacterial and viral production for $\mathrm{C}$ and $\mathrm{N}$ cycling in the Chukchi Sea are discussed
\end{abstract}

KEY WORDS: Microbiology $\cdot$ Ecology Arctic $\cdot$ Bacteriophage $\cdot$ Bacterial mortality

\section{INTRODUCTION}

Some of the highest rates of primary production in the world ocean have been measured in the northern Bering and southern Chukchi Seas (Sambrotto et al. 1984) and the intense productivity supports abundant populations of benthic invertebrates, seabirds, and marine mammals (Hood \& Calder 1981). The physical, chemical, and biological bases of this unusually productive area have been investigated in a number of

-E-mail: gsteward@ucsd.edu multidisciplinary research programs (e.g. Nagel 1992, McRoy 1993). The results suggest the region to have far-reaching biogeochemical importance as a sink for atmospheric $\mathrm{CO}_{2}$ (Walsh 1989) and a source of fixed carbon to the Arctic Ocean basins (Walsh et al. 1989).

Highest productivity in the Chukchi Sea occurs within modified Bering Shelf Water which we will refer to as BSAW after Grebmeier \& McRoy (1989), since it is a mixture of central Bering Shelf and eastern Anadyr Current Waters. To the east lies the much less productive Alaskan Coastal Water (ACW), which is distinguished by lower salinity and higher surface temperature due to inputs from rivers throughout the summer 
(Coachman et al. 1975) In microbiological studies of this regron, Andersen (1988) found that the significance of the microbial loop in respiration and $\mathrm{N}$ remincralization varied with location. In general, the microbial loop was estimated to process a large fraction (70) to $80 \%$ ) of primary productivity in the less productive ACW which is dominated by pico-and nanophytoplankton, but only a small fraction $(5 \%)$ in the highly productive, diatom-dominated BSAW. Subsequent reports (Hanson \& Robertson 1992, Kudryatsev et al. 1992) indicate higher rates of bacterial production, suggesting that the role of bacteria in this region may be greater than previously thought.

The fate of bacterial production was not explicitly examined in any of these studies, but data from temperate waters indicate that viral mortality of bacteria can sometimes be high (Proctor \& Fuhrman 1990, Steward et al. 1992b, Weinbauer et al. 1993) and should thus compete with protozoan grazing to affect the transfer of carbon and nitrogen through the food web (Fuhrman 1992, Murray \& Eldridge 1994). Whether the contribution of viruses to bacterial mortality is significant in polar pelagic food webs has not been studied.

The dynamics of bacteria and viruses in Arctic sea ice has recently been reported on (Maranger et al. 1994), but data on pelagic viruses in Arctic waters are scant, consisting of a single virus count from deep in the Barents Sea (Bergh et al. 1989) and 3 counts in the upper few meters underlying Arctic sea ice (Maranger et al. 1994). Somewhat more data have been presented for Antarctic waters and consist of a transect and some depth profiles of viral and bacterial abundance obtained during crossings of the Drake Passage (Smith et al. 1992). In all of these cases viral abundances were relatively low $\left(\leq 10^{9} \mathrm{l}^{-1}\right)$. Reports on the inhibition of marine bacteria by low temperature and substrate concentrations (e.g. Pomeroy et al. 1991) suggest that the low temperatures of polar waters may inhibit the production of bacteria, and secondarily, of bacterial viruses.

Adjacent areas of very high and low productivity in the Chukchi Sea provide an opportunity to examine variability in the ecology of viruses in cold Arctic waters. In this report, we present data on. the distribution, abundance and production of bacteria and bacterial viruses in the Bering and Chukchi Seas, estimate the contribution of viruses to bacterial mortality, and discuss the impact of bacteria and viruses on carbon and nitrogen cycling in relation to the reported variability of primary productivity of the study area.

\section{MATERIALS AND METHODS}

Sample collection. Samples were collected during cruise HX165 of the RV 'Alpha Helix' from 18 August to 14 September 1992. Sample sites are presented in Fig. 1. Seawater samples for depth profiles and/or rate measurements were collected with 10 I Niskin bottles mounted on a CTD rosette. Additional transect samples were collected from the uncontaminated seawater supply while underway (inlet at approximately $8 \mathrm{~m}$ depth). A sediment core was collected with a $0.0133 \mathrm{~m}^{2}$ Haps corer (Kanneworff \& Nicolaisen 1973) and a pore water sample extracted from the core using a wholecore squeezer (Brandes \& Devol 1995) which was based on the design of Bender et al. (1987).

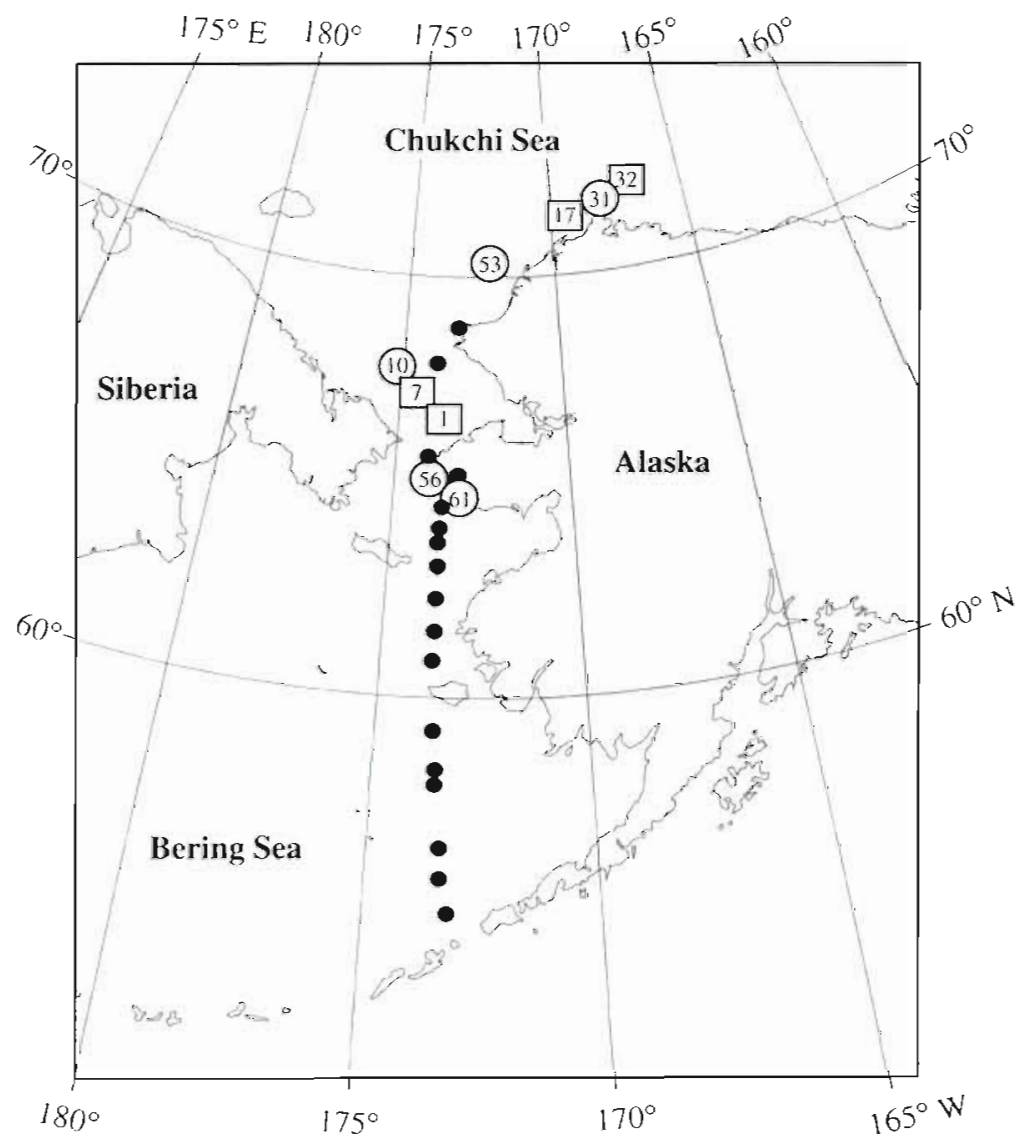

Fig. 1 The study area, with location of different station types showing: depth profiles (numbered squares), single surface samples collected with Niskin bottles (numbered circles), and transect samples collected from the uncontaminated seawater supply (filled circles). The sediment pore water sample was collected at Stn 31 
Enumeration of microorganisms. Samples were preserved with $2 \%$ glutaraldehyde ( $v: v$, final concentration) and stored in polypropylene tubes $(15$ or $50 \mathrm{ml}$ capacity) at $4^{\circ} \mathrm{C}$ until they could be processed ashore. Storage time varied from 9 to $37 \mathrm{~d}$. The microorganisms in $10 \mathrm{ml} \mathrm{sub-}$ samples were pelleted directly onto electron microscope grids as described in Cochlan el al. (1993) except that centrifugation was decreased to $2 \mathrm{~h}$ (sufficient to pellet particles of $60 \mathrm{~S}$ or larger). Grids were stained for $20 \mathrm{~s}$ in $0.5 \%$ uranyl acetate followed by 3 sequential 10 s rinses in Milli-Q $Q^{\oplus a t e r ~ E x c e s s ~ w a t e r ~ w a s ~ w i c k e d ~ a w a y ~ w i t h ~}$ bibulous paper (Whatman 3MM or equivalent) and the grids allowed to air dry. Grids were examined in a Hitachi H-500 transmission electron microscope (TEM) at an accelerating voltage of $100 \mathrm{kV}$. Each grid was examined at several different magnifications to count the various classes of microorganisms. Magnifications used were $31 \times$ for diatoms, $1000 \times$ for flagellates, 3000 to $10000 \times$ for bacteria, and $50000 \times$ for viruses. For diatoms, the count was determined by scanning the entire grid. For all others, 50 to 100 view fields were counted. For flagellates and bacteria, no attempt was made to discriminate between nutritional modes; all nanoflagellates and bacteria were assumed to be heterotrophic. Although thecae of choanoflagellates were observed in many samples, they were too few to quantify reliably and are not included in this report.

Frequency of infected cells. On the same grids that were used for enumeraling microorganisms, 500 bacteria per sample were examined by TEM at 30000 to $50000 \times$ magnification and scored as infected if they contained 3 or more intracellular virus-like particles. Intracellular virus-like particles were identified as darker staining spots having regular shape (circular to icosahedral in profile), all of the same size within any particular cell, and contained within the boundary of the cell envelope as viewed in profile. Virus-like particles can be distinguished from mineral inclusions (such as magnetite) due to tho electron opacity of the latter which renders them evenly black. When the scoring of a cell was uncertain, judgement was based on a photograph of the cull which provided higher resolution than the phosphorescent viewing screen. The frequency of visibly infected cells (FVIC) was converted to a frequency of infected cells (FIC) using the average (5.42) of the high (7.14) and low (3.7) conversion factors presented in Proctor et al. (1993). A conversion factor is needed to account for infected bacteria which do not yet contain mature virus particles and thus would not be scored as visibly infected. A range for the FIC estimate was obtained by calculating an extreme high value as the FVIC upper $95 \%$ confidence interval (CI) multiplied by the high conversion factor and an extreme low value as the FVIC lower $95 \%$ CI multiplied by the low conversion factor.
Bacterial production. Bacterial secondary production was determined by H-leucine incorporation (Kirchman et al. 1985, Simon \& Azam 1989) as modified for micro-centrifugation by Smith \& Azam (1992). Bacterial carbon production was converted to cell production assuming $20 \mathrm{fg} \mathrm{C}^{\mathrm{C}}$ cell $^{-1}$ (Lee \& Fuhrman 1987)

Bacterial virus production. Production rates of bacterial viruses (bacteriophages or phages) were estimated from ${ }^{3} \mathrm{H}$-thymidine ( $\mathrm{H}-\mathrm{Td} \mathrm{R}$ ) incorporation into bacteriophage DNA using a conversion factor of $2 \times$ $10^{21}$ viruses (mol TdR incorporated) ${ }^{-1}$ (Steward et al. 1992a). Errors in production rates are taken as the $95 \%$ $\mathrm{Cl}$ for the slope of the rate regression line. An diternative approach to estimating bacteriophage production was also employed. In this method, production was calculated by multiplying together FIC and bacterial production for each sample to estimate rate of cell lysis. Multiplying by an assumed burst size of 50 then yielded an estimate of bacleriophage production. The burst size used is the average! estimated by Heldal \& Bratbak (1991) and similar to the average burst size of 51 observed for rod-shaped cells (the numerically dominant morphotype) by Weinbauer \& Peduzzi (1994). The range of the bacteriophage production estimate was culculated as the minimum and maximum obtainable rates when combining the extremes of the ranges for the FIC and bacterial production values used in the calculation (burst size was assumed constant) The ranges for FIC estimates were calculated as described above and the ranges for individual bacterial production estimates were taken as the mean \pm the standard deviation of triplicate incubations.

Flagellate grazing. Grazing rates of nanoflagellates were estimated as the product of bacterial concentration, flagellate concentration and an assumed clearance rate of $10 \mathrm{nl} \mathrm{h}^{-1}$ flagellate ${ }^{\prime}$ (Fenchel 1982, Andersen \& Fenchel 1985). This clearance rate was chosen to facilitate comparison with the data of Andersen (1.988) from the same study area. Grazing rales were expressed in terms of carbon by assuming $20 \mathrm{fg} \mathrm{C}$ bacterium $^{-1}$ (Lee \& Fuhrman 1987) The upper and lower limits for grazing rate in a sample were calculated from the upper and lower $95 \% \mathrm{Cl}$ of the flagellate concentrations.

Bacterial mortality. The fraction of bacterial productıon lysed by viruses was estimated by multiplying the mean FIC by 2 . The factor of 2 is used to express mortality as a percentage of production and assumes (1) a steady state in bacterial abundance as well as lysis and reinfection, and (2) that phage latent period equals bacterial generation time (Proctor \& Fuhrman 1990) The possible range of viral mortality in each sample was calculaled using the extreme high and low estimates of FIC tor that sample (see above). For compari- 
son, bacterial mortality was also derived from radiolabeling estimates of viral production by assuming a burst size of 50. In this approach, viral production divided by burst size yielded an estimate of the rate of cell lysis which was then expressed as a percentage of bacterial cell production. The percent bacterial mortality due to grazing was calculated as the grazing rate divided by the bacterial production rate. The range for mortality due to flagellate ingestion was calculated from the range of each estimate of grazing rate (see above).

\section{RESULTS}

\section{Abundance and distribution of microorganisms}

Bacterial and viral abundance in the surface water (upper $10 \mathrm{~m}$ ) from 2 transects (first and second halves of the cruise) are plotted as a function of latitude for all 26 stations in the Bering and Chukchi Seas in Fig. 2. Bacteria varied from 0.21 to $2.1 \times 10^{9} \mathrm{I}^{-1}$ and viruses from 2.5 to $36 \times 10^{9} \mathrm{I}^{-1}$. Although there was considerable variability, bacterial abundance tended to decrease with increasing latitude and this trend was more pronounced in the southbound transect. Viruses
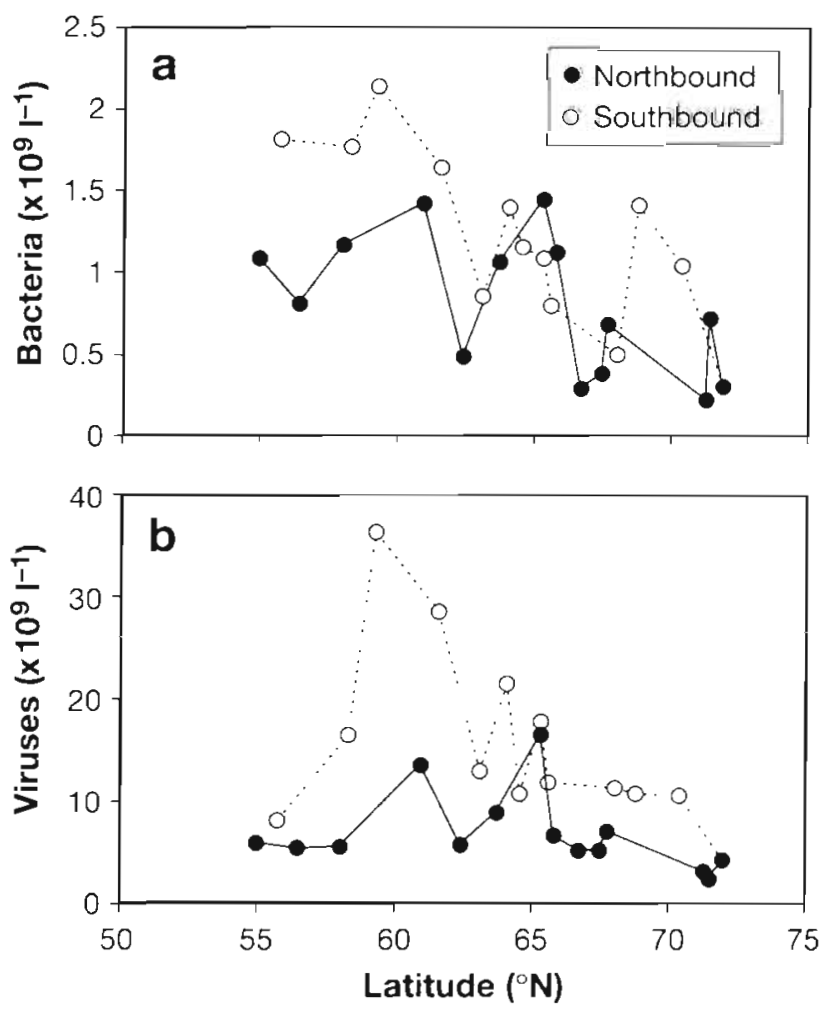

Fig. 2. Variation in the surface water concentrations of (a) bactena and (b) viruses with latitude during the northbound and southbound legs of the cruise displayed no obvious trend with latitude, but viral abundances were higher in the southbound relative to the northbound transect. In a sample of pore water squeezed from the upper $1 \mathrm{~cm}$ of a sediment core, bacteria and viruses were present at 2.1 and $27 \times 10^{9} \mathrm{I}^{-1}$. respectively.

For 3 of the stations in the Chukchi Sea we present depth profiles of temperature, salinity, in situ fluorescence, the abundances of bacteria, viruses, flagellates and diatoms, the FVIC and bacterial production in Fig. 3. Diatoms and flagellates displayed similar patterns of depth distribution with peaks below the mixed layer. The major peaks in diatom counts corresponded to fluorescence peaks measured by the in situ fluorometer. The fluorometer was not calibrated so these data could not be converted to chlorophyll concentrations. Bacteria and viruses were most abundant below the mixed layer, with both displaying sub-surface maxima at $100 \mathrm{~m}$ in the 2 deeper profiles (Stns 17 and 32. Fig. 3). In the deepest profile (Stn 32), bacteria and viruses show a steep decline with depth into waters of Atlantic Ocean origin below $120 \mathrm{~m}$ (Coachman \& Aagaard 1974), reaching minima of $0.067 \times 10^{9} \mathrm{bac}-$ teria $\mathrm{l}^{-1}$ at $195 \mathrm{~m}$ and $<0.1 \times 10^{9}$ viruses $\mathrm{l}^{-1}$ (below detection limit) at $264 \mathrm{~m}$.

Integrated biomass estimates for bacteria were 4 to 5 times higher in the north (Stns 17 and 32) relative to the south (Stns 1 and 7) when considering the entire water column (Table 1). Integration restricted to the upper $50 \mathrm{~m}$ at the deeper northern stations was also done to allow comparison with the southern stations over a similar depth interval. In this case, integrated bacterial biomass varied little amongst the 4 stations (Table 1).

\section{Bacterial production}

Bacterial production rates ranged from 0.15 to $17 \mathrm{\mu g}$ $\mathrm{C} \mathrm{I}^{-1} \mathrm{~d}^{-1}$. Considering only samples from above $100 \mathrm{~m}$, the lowest measured bacterial production was $1.8 \mu \mathrm{g} \mathrm{C}$ $\mathrm{l}^{-1} \mathrm{~d}^{-1}$. Water-column-integrated bacterial production at 4 stations (Table 1 ) showed little variation $(0.3$ to $0.45 \mathrm{~g} \mathrm{C} \mathrm{m}^{-2} \mathrm{~d}^{-1}$ ) despite the much shallower water column at the southern stations. Integrations restricted to the upper $50 \mathrm{~m}$ are also presented for the deeper northern stations. In this restricted integration, bacterial production is observed to be 2 to 2.5 times higher in the southern relative to the northern stations. Assemblage-averaged cell-specific growth rates ranged from 0.67 to $2.48 \mathrm{~d}^{-1}$ at the southern Stns 1 and 7 and from 0.06 to $0.84 \mathrm{~d}^{-1}$ at the northern Stns 17 and 32 . These growth rates correspond to turnover times of the bacterial pool ranging from 0.4 to $1.5 \mathrm{~d}$ in the south and 1.2 to $17 \mathrm{~d}$ in the north. 


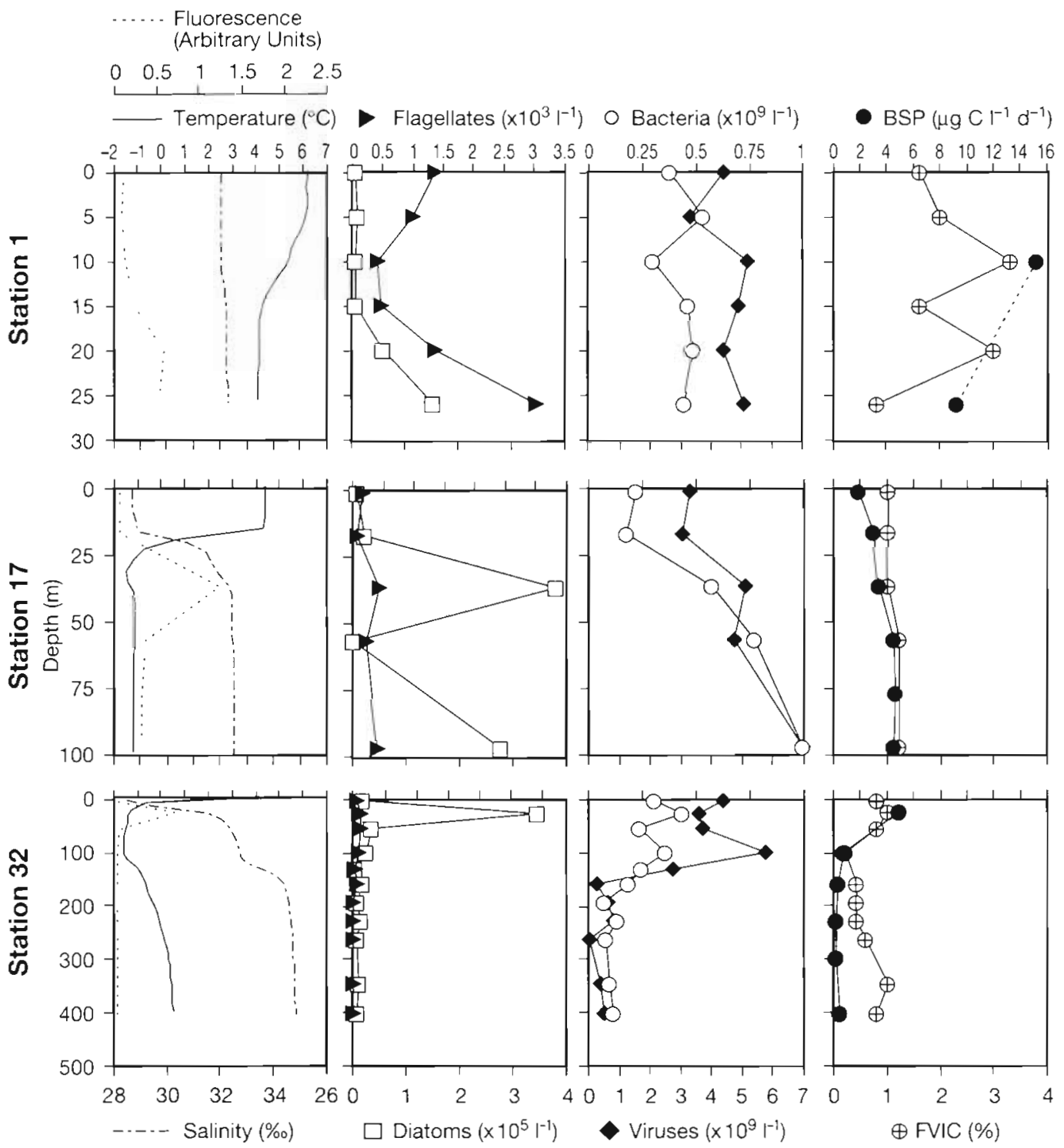

Fig. 3. Depth profiles of CTD/fluorometer data, microbial abundances, bacterial growth rates, and the frequency of visibly infected bacterial cells for Stns 1 (upper panels), 17 (middle panels) and 32 (lower panels). Data for all stations were presented using the same scales to facilitate qualitative comparison. BSP: bacterial secondary production; FVIC: frequency of visibly infected cells

Table 1. Integrated water column estimates of bacterial biomass, production, and mortality due to viral lysis and flagellate grazing at the 4 depth-profile stations. Bacterial mortality is presented as the mean with the range in parentheses

\begin{tabular}{|c|c|c|c|c|c|c|c|c|}
\hline \multirow{2}{*}{$\begin{array}{l}\text { Stn (max } \\
\text { depth) }\end{array}$} & \multirow{2}{*}{$\begin{array}{l}\text { Depth of } \\
\text { integration } \\
\text { (m) }\end{array}$} & \multirow{2}{*}{$\begin{array}{c}\text { Bacterial } \\
\text { biomass } \\
\left(\mathrm{mg} \mathrm{C} \mathrm{m}^{-2}\right)\end{array}$} & \multirow{2}{*}{$\begin{array}{c}\text { Bacterial C } \\
\text { prod } \\
\left.\text { (mg } C \mathrm{~m}^{-2} \mathrm{~d}^{-1}\right)\end{array}$} & \multirow[b]{2}{*}{$\begin{array}{c}\text { Bacterial } C \\
\text { lysed } \\
\left.\text { (mg } \mathrm{C} \mathrm{m}^{-2} \mathrm{~d}^{-1}\right)\end{array}$} & \multirow{2}{*}{$\begin{array}{l}\text { Bacteric } \\
\text { Bacterial C } \\
\text { ingested } \\
\left(\mathrm{mg} \mathrm{C} \mathrm{m}^{-2} \mathrm{~d}^{-1}\right)\end{array}$} & \multirow{2}{*}{$\begin{array}{l}1 \text { mortality } \\
\text { Viral } \\
\text { lysis } \\
\{\%\}\end{array}$} & \multirow[b]{2}{*}{$\begin{array}{c}\text { Flagellate } \\
\text { ingestion } \\
(\%)\end{array}$} & \multirow[b]{2}{*}{$\begin{array}{l}\text { Total } \\
(\%)\end{array}$} \\
\hline & & & & & & & & \\
\hline $1(30 \mathrm{~m})$ & Bottom & 261 & 384 & $89(33-144)$ & $88(63-113)$ & $23(9-37)$ & $23(17-30)$ & $46(25-67)$ \\
\hline $7(49 \mathrm{~m})$ & Bottom & 341 & 301 & $69(26-110)$ & $16(3-28)$ & $23(9-37)$ & $5(1-9)$ & $28(10-46)$ \\
\hline \multirow[t]{2}{*}{$17(105 \mathrm{~m})$} & 50 & 387 & 152 & $17(5-30)$ & $25(9-41)$ & $11(3-20)$ & $17(6-27)$ & $28(9-47)$ \\
\hline & Bottom & 1346 & 394 & $48(14-82)$ & $97(36-158)$ & $12(4-21)$ & $25(9-40)$ & $37(13-61)$ \\
\hline \multirow[t]{2}{*}{$32(406 \mathrm{~m})$} & 50 & 346 & 227 & $25(7-43)$ & $7(1-14)$ & $11(3-19)$ & $3(1-6)$ & $14(4-25)$ \\
\hline & Bottom & 1374 & 452 & $41(11-74)$ & $18(3-37)$ & $9(2-16)$ & $4(1-8)$ & $13(3-24)$ \\
\hline
\end{tabular}


Table 2. Estimates of viral production and of bacterial mortality due to viruses as obtained by 2 different methods: (A) calculated from FVIC and (B) calculated from incorporation of ${ }^{3} \mathrm{H}-\mathrm{TdR}$ into DNA of bacterial viruses. Data are presented as means and ranges (in parentheses), except viral production method B which is presented as means ( $\pm 95 \% \mathrm{CI}$ ). Stations are arranged in order of increasing latitude

\begin{tabular}{|c|c|c|c|c|c|c|}
\hline \multirow[t]{2}{*}{ Stn } & \multirow{2}{*}{$\begin{array}{l}\text { Depth } \\
\text { (m) }\end{array}$} & \multirow{2}{*}{$\begin{array}{l}\text { Lat, long. } \\
\left({ }^{\circ} \mathrm{N},{ }^{\circ} \mathrm{W}\right)\end{array}$} & \multicolumn{2}{|c|}{ Viral production } & \multicolumn{2}{|c|}{ Bacterial mortality } \\
\hline & & & $\begin{array}{l}\text { Method A } \\
\left(\times 10^{9} \mathrm{I}^{-1} \mathrm{~d}^{-1}\right)\end{array}$ & $\begin{array}{c}\text { Method B } \\
\left(\times 10^{9} \mathrm{I}^{-1} \mathrm{~d}^{-1}\right)\end{array}$ & $\begin{array}{c}\text { Method A } \\
\qquad(\%)\end{array}$ & $\begin{array}{c}\text { Method B } \\
(\%)\end{array}$ \\
\hline 61 & 3 & $65.28,166.40$ & $1.2(0.32-2.4)$ & & $13(4-22)$ & \\
\hline 56 & 4.8 & $65.54,168.03$ & $1.4(0.45-2.7)$ & & $22(8-35)$ & \\
\hline 1 & $\begin{array}{l}10 \\
26\end{array}$ & $66.67,167.38$ & $\begin{array}{c}14(4.0-28) \\
2.0(0.40-4.2)\end{array}$ & $\begin{array}{l}4.2( \pm 2.5) \\
2.0( \pm 1.4)\end{array}$ & $\begin{array}{c}36(13-59) \\
9(2-16)\end{array}$ & $\begin{array}{r}10(3.9-18) \\
7.7(2.1-15)\end{array}$ \\
\hline 7 & $\begin{array}{l}10 \\
22\end{array}$ & $67.40,168.90$ & $\begin{array}{l}4.6(1.2-9.5) \\
3.0(1.1-4.4)\end{array}$ & & $\begin{array}{l}20(7-32) \\
26(10-41)\end{array}$ & \\
\hline 53 & 5 & $70.32,164.65$ & $1.1(0.22-2.4)$ & $0.70( \pm 0.67)$ & $13(4-22)$ & $7.9(0.3-22)$ \\
\hline 17 & $\begin{array}{l}1.3 \\
17 \\
37 \\
57 \\
97\end{array}$ & $71.22,158.65$ & $\begin{array}{l}0.50(0.12-0.99) \\
0.77(0.14-1.8) \\
0.91(0.20-1.9) \\
1.4(0.34-3.0) \\
1.5(0.38-2.8)\end{array}$ & $0.51( \pm 0.56)$ & $\begin{array}{l}11(3-19) \\
11(3-19) \\
11(3-19) \\
13(4-22) \\
13(4-22)\end{array}$ & $1.9(0-5.8)$ \\
\hline 31 & 5.4 & $71.40,156.12$ & $0.39(0.08-0.79)$ & $1.5( \pm 1.2)$ & $9(2-16)$ & $12(2.3-22)$ \\
\hline 32 & $\begin{array}{r}26 \\
101 \\
160 \\
230 \\
402\end{array}$ & $71.88,154.97$ & $\begin{array}{c}1.3(0.27-2.8) \\
0.03(0.00-0.13) \\
0.03(0.00-0.09) \\
0.02(0.00-0.07) \\
0.08(0.01-0.17)\end{array}$ & & $\begin{array}{l}11(3-19) \\
2(0-6) \\
4(1-9) \\
4(1-9) \\
9(2-16)\end{array}$ & \\
\hline
\end{tabular}

\section{Bacteriophage production}

Production of bacterial viruses estimated by radiolabeling in 5 samples ranged from 0.51 to $4.2 \times$ $10^{9}$ viruses $\mathrm{l}^{-1} \mathrm{~d}^{-1}$ (Table 2) Assuming that the assemblage of free viruses is dominated by bacteriophages, turnover times for the virus pool would range from 1.2 to $15 \mathrm{~d}$. For comparison with radiolabeling, estimates of bacteriophage production were also calculated from FIC. With this calculation, production in the same 5 samples ranged from 0.39 to $14 \times 10^{9}$ viruses $\mathrm{l}^{-1} \mathrm{~d}^{-1}$ (Table 2) with turnover times ranging from 0.38 to $9.8 \mathrm{~d}$. The discrepancy between the approaches varied from as little as 4 up to $266 \%$, but in all cases the ranges obtained for each sample by the 2 independent methods are overlapping. Looking at all the data for bacteriophage production calculated from FIC, the highest estimated rates were observed in the southern Chukchi Sea at Stns 1 and 7 ( 2 to $14 \times 10^{9}$ viruses $\mathrm{l}^{-1} \mathrm{~d}^{-1}$ ) and the lowest rates were observed below $100 \mathrm{~m}$ at the northernmost Stn 32 $\left(0.02\right.$ to $0.08 \times 10^{9}$ viruses $\left.\mathrm{l}^{-1} \mathrm{~d}^{-1}\right)$. All other samples fell between 0.39 and $1.5 \times 10^{9}$ viruses $\mathrm{l}^{-1} \mathrm{~d}^{-1}$

\section{Virus-infected cells}

Virus-infected bacteria were observed in all of the 28 pelagic samples examined, ranging from 0.2 to $3.3 \%$ of the assemblage. Viruses were found in bacteria of varying morphologies and at different stages of infection with apparent burst sizes varying from 7 to $>270$ (Fig. 4). The only sample in which infection was not detected ( $<0.6 \%$ at $95 \%$ confidence limit) was the sediment pore water sample from Stn 30, although bacteria and viruslike particles were present at high concentrations.

Infections of flagellates could not be detected by the method employed here because of their much greater electron density, which prevented discrimination of intracellular features. Although chloroplasts could be distinguished in some diatoms, it is not known whether intracellular viruses would be visible without sectioning. While no virus-like particles were observed in diatoms, a systematic search was not performed.

\section{Bacterial mortality}

The percentage of bacterial mortality attributable to viral lysis as calculated from the FVIC ranged from 2 to $36 \%$ (Table 2). Including uncertainties in the determination of FVIC as well as in the conversion factor (see 'Materials and methods'), the potential range of mortality due to viruses becomes $<1$ up to $59 \%$. Similar to viral production, highest estimates of viral mortality of bacteria were found in the southern Chukchi Sea at Stns 1,7 and $56(9$ to $36 \%)$. Lowest estimates were observed below $100 \mathrm{~m}$ at the northernmost Stn 32 (2 to $9 \%$ ). Mortality at the remaining stations varied only from 9 to $13 \%$. For comparison, viral mortality of bacteria was also estimated from viral production rates 


\section{a}
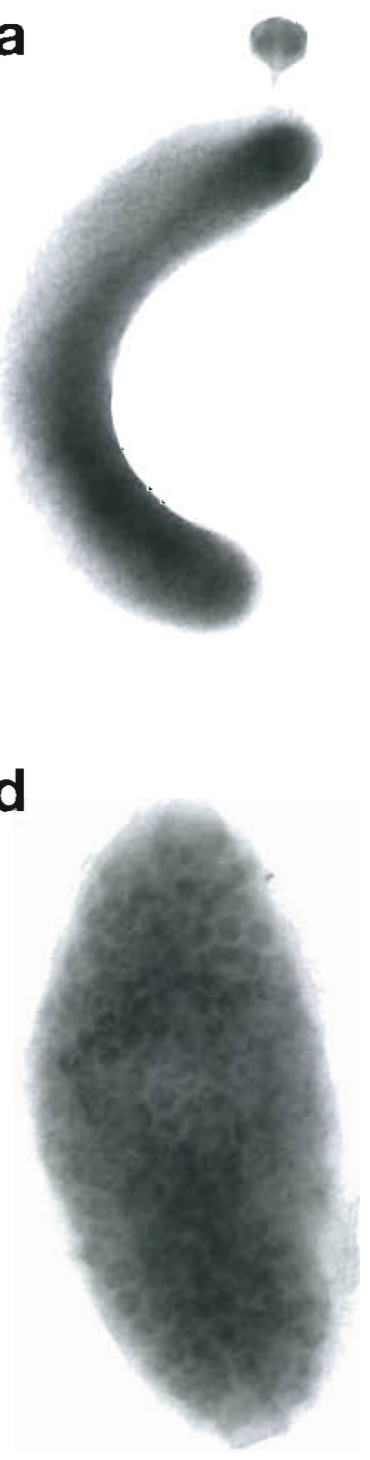
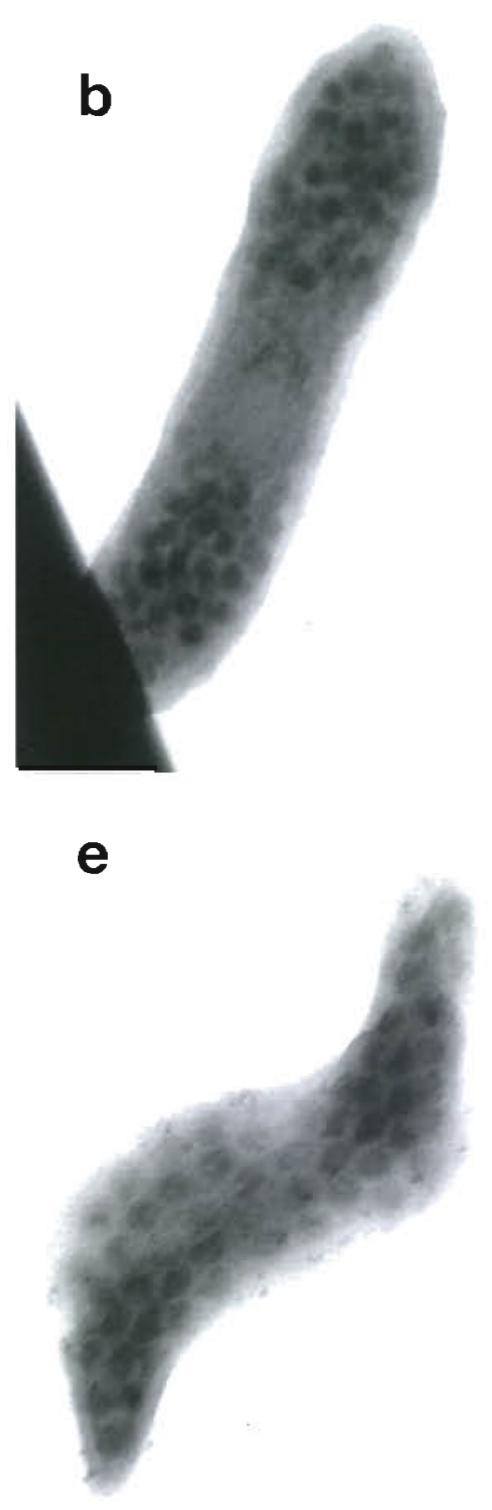

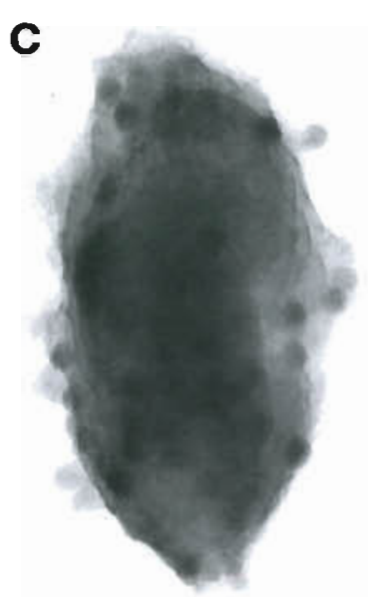

f

Fig. 4. Transmission electron micrographs showing different stages of infection of bacteria by viruses (a-c) and the variation in apparent burst sizes $(\mathrm{d}-\mathrm{f})$. Individual photos and sample locations are: (a) a tailed virus adsorbed to a bacterium (transect station $64^{\circ} \mathrm{N}, 167^{\circ} \mathrm{W}, 8 \mathrm{~m}$ depth); (b) a bacterum partially filled with mature virus particles (Stn $17,97 \mathrm{~m} \mathrm{depth);} \mathrm{(c)} \mathrm{a} \mathrm{bacterium}$ apparently at the point of bursting and releasing mature virus particles ( $\operatorname{Stn} 53.5 \mathrm{~m}$ depth); (d) a bacterium with a burst size of $>170(\operatorname{Stn} 32,160 \mathrm{~m}) ;(e)$ a bacterium with a burst size of approximately $50(\operatorname{Stn} 32,160 \mathrm{~m})$; (f) a bacterium with a burst size of approximately $7(\operatorname{Stn} 7,10 \mathrm{~m})$. Full length of scale bar equivalent to $0.5 \mu \mathrm{m}$. Length of the thick, central portion of scale bar equivalent to $100 \mathrm{~nm}$

obtained using the radiolabeling approach. Mortality estimates thus obtained ranged from 1.9 to $12 \%$ of the bacterial cell production (Table 2 )

Estimated mortality due to grazing by flagellates ranged from 0 to $125 \%$ (data not shown). The ratio of viral lysis to flagellate ingestion of bacteria is plotted versus depth for all samples where both sources of mortality were measured or could be estimated (Fig. 5). The lysis/grazing ratio varied from 0.08 to 12.2 . Viral lysis predominated (ratio $>1$ ) as frequently as flagellate grazing (ratio $<1$ ), but the distribution varied with depth. Viral lysis predominated in most of the near-surface samples $(0$ to $30 \mathrm{~m}$ ) and in the deepest water samples (below $300 \mathrm{~m}$ ), while flagellate grazing predominated in all of the mid-water samples ( 50 to $250 \mathrm{~m}$ ).

Averaged over the water column at the 4 depthprofile stations, viral mortality of bacteria varied from 9 to $23 \%$ with higher percentages at the 2 stations in 


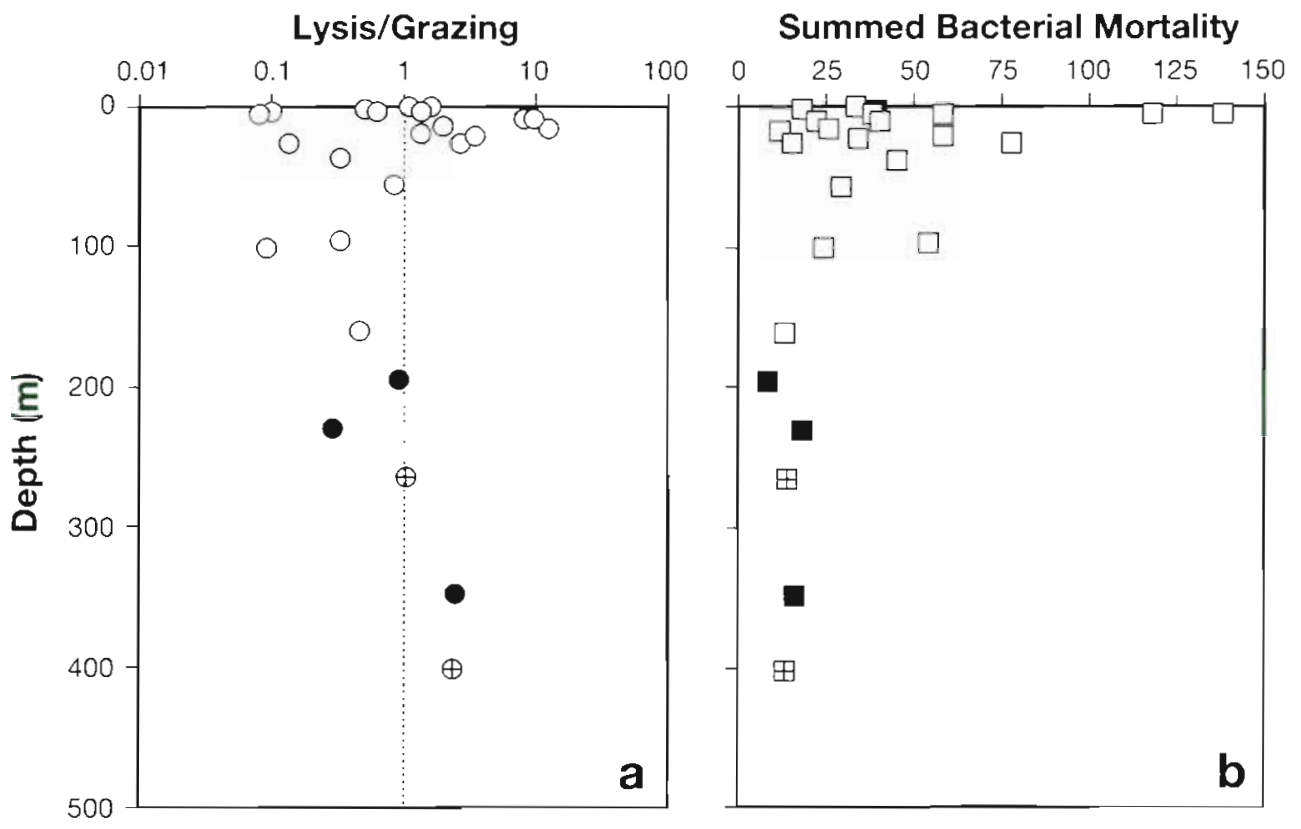

Fig. 5. Variation with depth of (a) the ratio of bacterial mortality due to viral lysis versus flagellate grazing and (b) total estimated percent bacterial mortality calculated as the sum of mortality due to viral lysis and flagellate grazing; mortality is presented as the percent of bacterial production. Plots are compilations of all samples in this study for which data were available or could be estimated. Open circles and open squares are for samples where both lysis and grazing data were directly calculated. Filled and crossed symbols are for samples where flagellates were below the detection limit. In these samples we calculated maximum grazing rate (therefore minimum lysis/grazing ratio and maximum mortality) by assuming that flagellates were exactly at the detection limit. In 2 of those samples, the bacterial production measurements required to estimate grazing mortality were not available and were estimated by interpolation between the nearest higher and lower depths in the depth profile (crossed circles and squares]

the southern Chukchi Sea relative to the 2 northern stations (Table 1). The corresponding water-column averages of mortality due to flagellate grazing varied from 4 to $25 \%$. In absolute terms, these percentages imply the lysis of 41 to $89 \mathrm{mg} \mathrm{C} \mathrm{m}^{-2} \mathrm{~d}^{-1}$ by viruses and the ingestion of 16 to $97 \mathrm{mg} \mathrm{C} \mathrm{m} \mathrm{m}^{-2} \mathrm{~d}^{-1}$ by flagellates.

\section{Correlations}

Viral and bacterial abundances were positively correlated ( $r=0.81, n=41$; Fig. 6a) with a virus/bacteria ratio of $10 \pm 5.5$ (mean $\pm \mathrm{SD}$ ). FVIC (and therefore percent mortality) correlated with bacterial production $(\mathrm{r}=0.75, \mathrm{n}=18$; Fig. $6 \mathrm{~b})$ and average bacterial cellspecific growth rate ( $r=0.74, n=18$; not shown), but not with bacterial abundance $(r=0.22, n=27$; Fig $6 c$ )

\section{DISCUSSION}

\section{Abundance and production of bacteria and viruses}

General patterns in the distributions of bacteria and viruses in surface waters were roughly consistent be- tween the northbound and southbound transects, but abundances of viruses and, to some extent, bacteria were higher during the southbound transect. This may reflect real increases in bacterial and viral populations throughout the region from the beginning to the end of the cruise ( $28 \mathrm{~d}$ ). It is also possible that part or all of the difference could be due to longer storage time of the samples collected during the first half of the cruise.

Decreases in bacterial abundance in fixed, stored samples have been documented (Turley \& Hughes 1992), but these results were for samples stored at room temperature and counted by epifluorescence microscopy. The effect of storage at $5^{\circ} \mathrm{C}$ on counts of bacteria and viruses by electron microscopy (the conditions in this study) has not been rigorously tested. However, in a preliminary test in our laboratory, after $40 \mathrm{~d}$ of storage, numbers of bacteria decreased by $23 \%$ and those of viruses by $66 \%$ in samples of water collected from the pier at Scripps Institution of Oceanography (authors' unpubl, results). These results are consistent with the discrepancy between the earlier-collected (northbound) and later-collected (southbound) transects and provide a possible explanation for why the discrepancy is more pronounced for viruses. Whether, or to what extent, the differences are due to storage arti- 

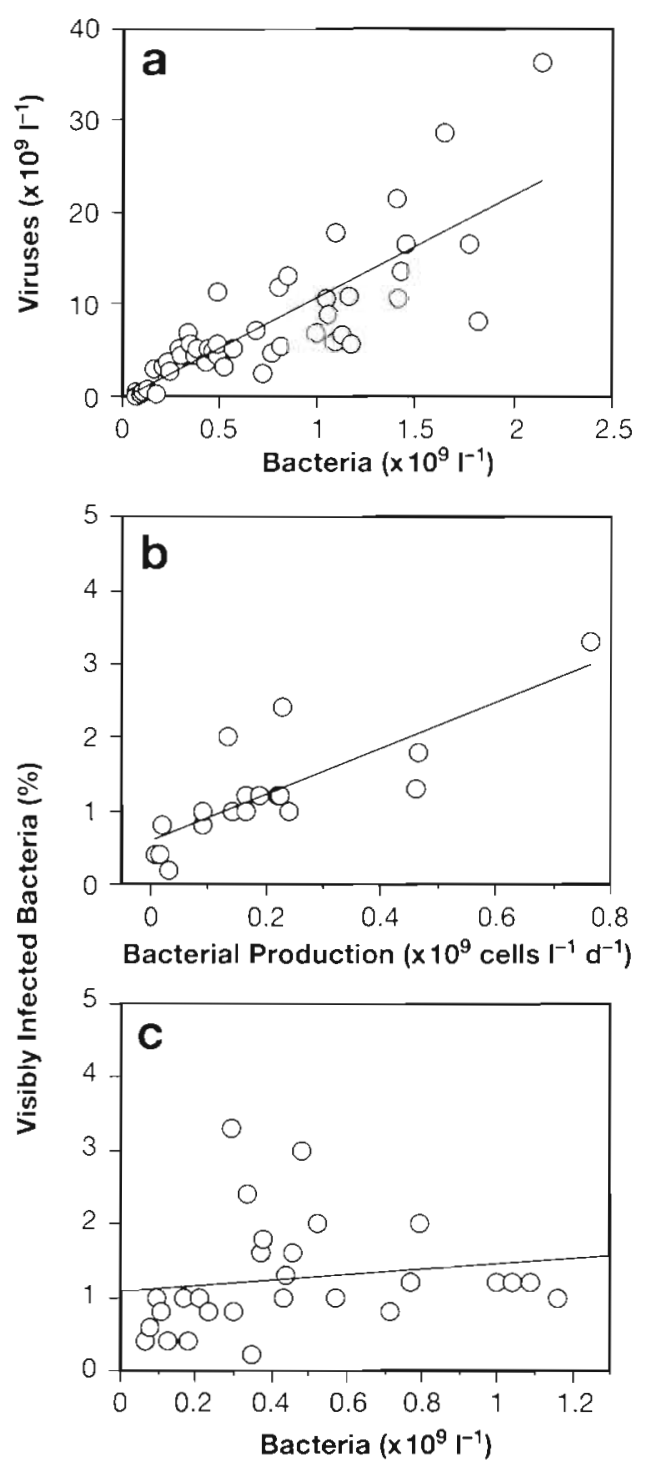

Fig. 6. Correlations of (a) viral versus bacterial abundance, (b) FVIC versus bacterial production and (c) FVIC versus bacterial abundance. Lines through each data set are leastsquares linear regressions with the respective equations and goodness of fit being (a) $y=11.03 x+0.28, r^{2}=0.66$; (b) $y=$ $3.15 x+0.59, r^{2}=0.64 ;$ (c) $y=0.40 x+1.07, r^{2}=0.03$

fact or reflect real changes in abundance is not possible to say, so we can only note that our bacteria and virus numbers may be underestimated.

Our estimates of bacterial abundance and biomass, as well as heterotrophic nanoflagellate abundance and production, are comparable to previous results from the same area (Andersen 1988). Our estimates of bacterial production $\left(0.30\right.$ to $0.45 \mathrm{~g} \mathrm{C} \mathrm{m}^{-2} \mathrm{~d}^{-1}$ ) fall in the range of some previous results for this region obtained using different techniques. In the Chukchi Sea, overlapping rates were inferred by Kudryatsev et al. (1992) using a dark $\mathrm{CO}_{2}$-incorporation technique 10.3 to $1.1 \mathrm{~g} \mathrm{C} \mathrm{m}^{-2} \mathrm{~d}^{-1}$ ). In the Bering Sea, Hanson \& Robertson (1992) used ${ }^{3} \mathrm{H}-\mathrm{TdR}$ incorporation to measure production rates of 0.22 and $0.24 \mathrm{~g} \mathrm{C} \mathrm{m}^{-2} \mathrm{~d}^{-1}$ in ACW and BSAW, respectively, but based on the frequency of dividing cells their estimates for the same stations were 3 to 4 times higher $\left(0.62\right.$ and $1.0 \mathrm{~g} \mathrm{C} \mathrm{m}^{-2}$ $\mathrm{d}^{-1}$, respectively). These estimates of bacterial production are about 1 to 2 orders of magnitude higher than the thymidine-based rates reported by Andersen (1988) for the Chukchi Sea.

Viruses were not included in any of the previous investigations of Arctic marine food webs, but our data indicate that they are a ubiquitous and dynamic component and that they can be a significant, though variable, source of bacterial mortality. Consistent with data from other areas, viruses were an order of magnitude more abundant than bacteria on average and their concentrations spanned much of the range observed in a wide variety of marine environments (e.g. Bergh et al. 1989, Hara et al. 1991, Smith et al. 1992, Wommack et al. 1992, Cochlan et al. 1993, Paul et al. 1993, Weinbauer et al. 1993).

Production estimates of bacterial viruses obtained by 2 different methods (radiolabeling versus calculation from FVIC) gave similar results and indicated production rates comparable to those found in temperate oceanic waters of the Southern California Bight, USA (Steward et al. 1992b). An imprecise agreement between the 2 methods is to be expected given our simplifying assumption of a constant average burst size in the conversion of FVIC to viral production. Reported burst sizes range widely from 6 to 300 (Heldal \& Bratbak 1991, Weinbauer \& Peduzzi 1994, this study). Thus, while variations could easily explain any discrepancy between the methods, better constraints on this variable must be made before it can be concluded that the methods are in agreement. Although we have used production rates of bacterial viruses to calculate bacteriophage pool turnover, we note that it is not possible to distinguish bacteriophages from other viruses by electron microscopy. Therefore, in assuming that bacteriophages comprise the vast majority of the total virus count, we may have overestimated the size and the turnover time of the bacterial virus pool.

\section{Viral infections of bacteria}

The percent of bacteria containing mature viruses (i.e. FVIC) observed in this study $(0.2$ to $3.3 \%)$ is similar to the ranges found previously in temperate and tropical waters. FVIC in these studies ranged from 0.9 to $4.3 \%$ for a variety of marine environments (Proctor \& Fuhrman 1990), from 0.7 to $3.7 \%$ in particle-associated 
bacteria obtained from sediment trap material (Proctor \& Fuhrman 1991) and from 0 to $4.2 \%$ in the northern Adriatic Sea (Weinbauer et al. 1993, Weinbauer \& Peduzzi 1994) Some of the above data were obtained by direct examination of whole bacteria as in this study (Weinbauer references) and some by examination of thin sections of embedded bacterial concentrates (Proctor references). In a direct comparison of thin sectioning versus whole cell methods the latter was found to yield a lower FVIC, possibly due to difficulty in detecting intracellular viruses in some unsectioned cells (Fuhrman \& Noble 1995) Other experiments suggest that underestimation of FVIC in the whole cell method could result when cells are pelleted using a high relative centrifugal field (as in this study), possibly due to rupture of some infected cells (M. Weinbauer pers. comm.). Further investigation is necessary to determine the source and consistency of this discrepancy. However, these results suggest that our estimates of FVIC are likely to be conservative.

All of the FVIC data discussed above are in marked contrast to data obtained using streptomycin-induced lysis of bacteria to release intracellular viruses prior to examination by electron microscopy. Using this approach, virus-producing cells have been estimated at 8 to $14 \%$ (Heldal \& Bratbak 1991) and 12 to $29 \%$ (Bratbak et al. 1992) of the bacterial assemblage. However, it is not clear whether the virus-producing cells as defined by the lysis-from-without method are equivalent to visibly infected cells. Difficulty in reconciling measured bacterial production with the extremely high bacterial mortality implied by these estimates leaves the proper interpretation of these infection data in question (Bratbak et al. 1992).

We found FVIC in seawater samples to be correlated with both bacterial production and average bacterial cell-specific growth rate. However, contrary to the data of Weinbauer et al. (1993), FVIC was not correlated with bacterial abundance. It is possible that differences in correlations between the studies are due to differences in sample storage and processing. Alternatively; they may reflect real differences in the structure of the microbial food web in different locations. For example whether viral production is predominantly due to lytic propagation or the induction of lysogens could affect the relationship between FIC and other variables. Few studies have been done, but available evidence argues for the importance of both lytic (Wilcox \& Fuhrman 1994) and temperate phages (Jiang \& Paul 1994) in marine waters. Regardless of the mode of viral infection or the exact nature of the relationship between viral and bacterial production, our data support the previous general conclusions that viruses exert a greater influence in more eutrophic waters (Steward et al. 1992b, Weinbauer et al. 1993).

\section{Bacterial mortality}

If the current interpretation of FVIC in terms of bacterial mortality (Proctor et al. 1993) is correct, then our data suggest that viruses can contribute significantly to losses of bacterial production in Arctic waters, not only in individual samples (up to $36 \%$ ), but also averaged over the water column (up to $23 \%$ ) Although we used whole cells rather than thin sections for determining FVIC, in preliminary work it was found that the range in conversion factor derived using the whole cell method on natural communities $(3.9$ to $6.6 ; \mathrm{M}$. Weinbauer pers. comm.) was within the range calculated by Proctor et al. (1993) using thin-sectioned material (3.7 to 7.14). However, given the possibility that we have underestimated FVIC (see discussion above), viruses are likely to contribute even more to bacterial mortality than we have estimated.

Bacterial mortality values calculated from viral production estimates overlap with those calculated from FV'IC, suggesting that the assumptions in interpreting FVIC may be reasonable. As discussed above regarding viral production, the agreement between FVIC and radiolabeling methods may be affected by variations in mean burst size, which we have assumed to be constant. Despite the overlapping values using 2 different methods, there are large uncertainties in estimates obtained by either approach. While the results are encouraging, further constraints on such mortality estimates are needed before it can be concluded that these methods are in agreement.

Overall, the estimated contributions of viruses and flagellates to bacterial mortality were comparable when integrated over the water column. This is a significant departure from the traditional view that flagellates are the major source of bacterial mortality (for reviews see McManus \& Fuhrman 1988, Pace 1988). However, similar results have recently been found in mesocosm experiments in temperate coastal waters (Fuhrman \& Noble 1995). Our conclusions regarding the relative contributions to bacterial mortality of viruses versus flagellates should be treated with some reservation given the assumptions and uncertainties in both mortality estimates. Uncertainties are reflected to some extent in the large possible range associated with. each estimate, but not every source of error is included. For example, the range for flagellate mortality would have been much wider, spanning several orders of magnitude, if we had included the full range of reported clearance rates for flagellates 10.07 to 336 ; compiled data from Eccleston-Parry \& Leadbeater 1994). Even with this uncertainty, our study highlights the variability with depth in both the absolute and relative impact of viruses and flagellates on bacteria This variation in the fate of bacterial production has 
important ecological and biogeochemical implications as it suggests depth-dependent changes in carbon flow pathways through the microbial food web

In this study our estimates of viral lysis and flagellate grazing account for less than $50 \%$ of the bacterial mortality in the majority of the samples (Fig 5). Mortality estimates less than $100 \%$ are not necessarily surprising as we have not included all possible sources of bacterial losses (having excluded grazing by ciliates and choanoflagellates, autolysis, loss from the water column by attachment to sinking particles, etc.). It is also possible that we have underestimated viral mortality (as discussed above) and/or flagellate grazing However, the percent mortality of bacteria accounted for by viruses and flagellates in all of the deeper water samples (200 to $402 \mathrm{~m}$ ) and some surface samples was particularly small $(<20 \%)$, suggesting the importance of alternative sources of mortality in those samples.

\section{Bacterial contribution to $\mathrm{C}$ and $\mathrm{N}$ dynamics}

When integrated over the entire water column, bacterial production was remarkably uniform at the 4 depth-profile stations $\left(0.30\right.$ to $\left.0.45 \mathrm{~g} \mathrm{C} \mathrm{m}^{-2} \mathrm{~d}^{-1}\right)$ despite the reported extreme spatial variability in primary production in the Chukchi Sea (Springer \& McRoy 1993). This suggests that the contribution of bacteria to carbon and nitrogen cycling varies dramatically with location within the Chukchi Sea.

For example, in BSAW in the southern Chukchi Sea, previous studies have shown high annual primary productivity reaching $470 \mathrm{~g} \mathrm{C} \mathrm{m}^{-2}$, while in the ACW, annual primary production is only $80 \mathrm{~g} \mathrm{C} \mathrm{m}^{-2}$ (Springer \& McRoy 1993). Based on geographic location, temperature and salinity signatures of the water masses (Coachman et al. 1975), and benthic respiration data collected during this cruise (J. Grebmeier pers. comm.), it is believed that at least one of our depth-profile stations (Stn 7) lay within the high, and at least one (Stn 1) within the low productivity region. However, since primary production data were not collected during our cruise, it is not certain what rates of productivity are appropriate for which stations. Therefore, we compare the range of bacterial carbon demand (BCD) estimates for all 4 stations with the above potential range of primary production.

To calculate conservative estimates of $\mathrm{BCD}$ from our bacterial production data, we assume a bacterial growth yield of $30 \%$, which is at the high end of some recent estimates (Bjørnsen 1986, Kirchman et al. 1991, Pomeroy et al. 1995, Smith et al. 1995). Annual BCD is then estimated assuming that bacteria grow at the observed rates for $90 \mathrm{~d}$ ( $3 \mathrm{mo}$, from mid-summer to late summer/early fall). Conservatively estimated bacterial carbon demand for all 4 stations then ranges from 1 to $1.5 \mathrm{~g} \mathrm{C} \mathrm{m}^{-2} \mathrm{~d}^{-1}$, totaling 90 to $137 \mathrm{~g} \mathrm{C} \mathrm{m}^{-2}$ annually, depending on the station. The calculated BCD accounts for at least 19 to $29 \%$ of the annual primary production expected in the BSAW. This is substantially higher than the 5\% estimated by Andersen (1988), even though the latter estimate included production and respiration of the entire microbial loop.

In the less productive waters of the $\mathrm{ACW}$, our estimated $\mathrm{BCD}$ implies carbon consumption equivalent to $113-170 \%$ of the annual primary production (PP). Again this is higher than the previous estimate $(80 \%)$ for this water mass calculated by Andersen (1988). Bacterial carbon demand exceeding $100 \%$ of the primary production in ACW could occur as the result of substantial recycling of organic matter (Strayer 1988) and/or its import by advection from other areas. The high $\mathrm{BCD} / \mathrm{PP}$ ratio suggests the possibility that there are times and/or regions of net heterotrophy within the Chukchi Sea which, along with organic matter sedimentation onto the shelf and export to the Arctic basin (Walsh et al. 1989), would serve to balance the exceptionally high autotrophic production in the northern Bering and southern Chukchi Seas.

With some additional assumptions we can use our data to estimate the importance of bacteria in $\mathrm{N}$ remineralization. We assume $\mathrm{C}: \mathrm{N}$ ratios of 4 for bacteria (Lee \& Fuhrman 1987) and 7 for phytoplankton (Goldman et al. 1979) and consider bacteria to consume organic matter with a $\mathrm{C}: \mathrm{N}$ ratio similar to that of phytoplankton. Remineralization of $\mathrm{N}$ is then calculated as the difference between nutrient consumed and nutrient assimilated (Caron \& Goldman 1990). With these assumptions, we calculate remineralization by bacteria to be 79 to $120 \mathrm{mg} \mathrm{N} \mathrm{m}^{-2} \mathrm{~d}^{-1}$ Using $\mathrm{N}$ requirements of phytoplankton calculated from the $\mathrm{C}: \mathrm{N}$ ratio and the primary production rates cited above, microbial remineralization could contribute 12 to $19 \%$ of the annual total photosynthetic $N$ requirement in the BSAW and 73 to $111 \%$ in the $\mathrm{ACW}$ Although only rough estimates, these values correspond with observed patterns of $\mathrm{N}$ utilization (Walsh et al. 1989) which indicate that primary production in BSAW is mostly nitrate-based, or new production $(80 \%)$, while in ACW the nitratebased production is only $10 \%$ of the total. Nitrogen supplied by bacterial remineralization thus has the potential to supply much or all of the regenerated $\mathrm{N}$ requirement in both water masses.

These calculations reveal a pattern consistent with the previous observation that the microbial loop processes a larger fraction of the primary production in the ACW relative to the highly productive BSAW (Andersen 1988, Walsh et al. 1989). However, the substantially higher rates of bacterial production which we have measured consistent with more recent estimates 
in the Chukchi Sea) suggest that the significance of bacteria in $\mathrm{C}$ and $\mathrm{N}$ cycling might be greater than previously appreciated.

\section{Implications of viral mortality of bacteria}

Since significant fractions of primary production can be processed by bacteria in the Chukchi Sea, the fate of the bacterial production may be an important variable for understanding biogeochemical pathways. Whether bacteria are lysed by viruses or consumed by flagellates is expected to affect the transfer of material and energy through the food web (Fuhrman 1992, Murray \& Eldridge 1994). By analysis of model food webs, Murray \& Eldridge (1994) concluded that viruses would only affect biomass transfer to higher trophic levels in oligotrophic, microbial-loop-dominated ecosystems, and even then only at relatively high viral mortality (e.g. $>50 \%)$.

Our results and the results of others (Weinbauer et al. 1993) indicate that viral mortality of bacteria is higher in more eutrophic waters (around 20 to $50 \%$ ), but is relatively slight (perhaps $10 \%$ ) in oligotrophic conditions where viruses would have the greatest potential impact. Thus, our results combined with the model results of Murray \& Eldridge (1994) imply that bacterial viruses might be expected to have little effect on zooplankton production under most circumstances. However, simple quantitative estimates of viral lysis of bacteria and its effect on carbon supply to higher trophic levels may misrepresent the significance of bacteria and bacterial viruses in biogeochemical cycling.

Even in areas such as the northern Chukchi Sea, where integrated viral mortality averaged only $10 \%$, bacterial viruses are still likely to be critical components of the food web. Unlike protozoa, viruses are generally species-specific (Ackermann \& DuBow 1987. Børsheim 1993). Therefore, even when total viral mortality of bacteria is low, viruses could be devastating individual bacterial populations (e.g Bratbak et al. 1990) and thereby causing species succession and possibly maintaining species diversity as speculated by Fuhrman (1992).

Bacterial viruses may also shape the biochemical potential of the microbial community through genetic transfer among bacteria. Viruses could enhance genetic transfer directly, via transduction, or indirectly by contributing to the dissolved DNA pool, thus increasing the likelihood of natural transformation. Both processes have been shown to occur in aquatic environments (Saye et al. 1990, Frischer et al. 1994). The genes of bacterial viruses themselves may prove important determinants of bacterial phenotype through phage conversion. For example, it is known that some bacterial toxins, somatic antigens, and enzymes are actually coded by viral genes (Barksdale \& Arden 1974). To what extent viruses mediate species succession, the maintenance of bacterial diversity, genetic exchange, and conversion in natural seawater communities remains an important question to be answered However, our data from the Chukchi Sea imply that viral infection of pelagic bacteria is ubiquitous. Therefore, detailed investigation of these processes is critical to a complete understanding of the microbial ecology and biogeochemical dynamics of the Arctic marine ecosystem.

Acknowledgements. We thank A. Devol for the opportunity to participate in the cruise and for use of the squeeze core apparatus, J. Grebmeier and L. Cooper for providing a sediment core, S. Hartz and J. Smithhissler for assistance in sample collection and CTD data, and M. Flanagan for assistance in the preparation of Fig. 1. Thanks to M. Weinbauer and J. Fuhrman for discussion and provision of unpublished data, and to J. T Hollibaugh and 2 anonymous reviewers for suggestions to improve the manuscript. This research is in partial fulfillment of the requirements towards obtaining a PhD by G.F.S. This work was supported by NSF grants DPP91-13919 and OCE92-19864 to F.A. and NSF DPP91-14414 to J. T. Holli. baugh. Ship time was supported by NSF grant DPP-114287 to A. Devol.

\section{LITERATURE CITED}

Ackermann HW, DuBow MS (1987) Viruses of prokaryotes, Vol I. General properties of bacteriophages. CRC Press Inc, Boca Raton

Andersen P (1988) The quantitative importance of the 'microbial loop' in the marine pelagic: a case study from the North Bering/Chukchi seas. Arch Hydrobiol Beih 31:243-251

Andersen P, Fenchel T (1985) Bacterivory by microheterotrophic flagellates in seawater samples. Limnol Oceanogr 30:198-202

Barksdale L, Arden SB (1974) Persisting bacteriophage infections, lysogeny, and phage conversions. A Rev Microbiol 28:265-299

Bender M, Grande $K$, Johnson K, Marra J, Williams PJL, Sieburth J, Pilson $M$, Langdon $C$, Hitchcock $G$, Orchardo J, Hunt C. Donaghay P (1987) A comparison of four methods for determining planktonic community production. Limnol Oceanogr 32:1085-1098

Bergh $\varnothing$, Børsheim KY, Bratbak G. Heldal M (1989) High abundance of viruses found in aquatic environments Nature 340:467-468

Bjørnsen PK (1986) Bacterioplankton growth yield in continuous seawater cultures. Mar Ecol Prog Ser 30:191-196

Børsheim K (1993) Native marine bacteriophages. FEMS Microbiol Ecol 102:141-159

Brandes JA, Devol AH (1995) Simultaneous nitrate and oxygen respiration in coastal sediments - evidence for discrete diagenesis. J mar Res 53:771-797

Bratbak G, Heldal M, Norland S, Thingstad TF (1990) Viruses as partners in spring bloom microbial trophodynamics Appl environ Microbiol 56:1400-1405

Bratbak G, Heldal M, Thingstad TF, Riemann B, Haslund $\mathrm{OH}$ (1992) Incorporation of viruses into the budget of 
microbial C-transfer. A first approach. Mar Ecol Prog Ser $83: 273-280$

Caron DA, Goldman JC (1990) Protozoan nutrient regeneration. In: Capriulo GM (ed) The ecology of marine protozoa. Oxford University Press, New York, p 283-306

Coachman LK, Aagaard K (1974) Physical oceanography of Arctic and Subarctic Seas. In: Herman Y (ed) Marine geology and oceanography of the Arctic seas. SpringerVerlag, New York, p 1-72

Coachman LK, Aagaard K, Tripp RB (1975) Bering Strait: the regional physical oceanography. University of Washington Press, Seattle

Cochlan WP, Wikner J, Steward GF, Smith DC, Azam F (1993) Spatial distribution of viruses, bacteria and chlorophyll a in neritıc, oceanıc and estuarine environments. Mar Ecol Prog Ser 92:77-87

Eccleston-Parry JD, Leadbeater BSC (1994) A comparison of the growth kinetics of six marine heterotrophic nanoflagellates fed with one bacterial species. Mar Ecol Prog Ser 105:167-177

Fenchel T (1982) Ecology of heterotrophic microflagellates. IV. Quantitative occurrence and importance as bacterial consumers. Mar Ecol Prog Ser 9:35-42

Frischer ME, Stewart GJ, Paul JH (1994) Plasmid transfer to indigenous marine bacterial populations by natural transformation. FEMS Microbiol Ecol 15:127-136

Fuhrman J (1992) Bacterioplankton roles in cycling of organic matter: the microbial food web. In: Falkowski PG, Woodhead AD (eds) Primary productivity and biogeochemical cycles in the sea. Plenum Press, New York, p 361-383

Fuhrman JA, Noble RT (in press) Viruses and protists cause similar bacterial mortality in coastal seawater Limnol Oceanogr 40:1236-1242

Goldman JC, McCarthy JJ, Peavey GD (1979) Growth rate influence on the chemical composition of phytoplankton in oceanic waters. Nature 279:210-215

Grebmeier JM, McRoy PC (1989) Pelagic-benthic coupling on the shelf of the northern Bering and Chukchi Seas. III. Benthic food supply and carbon cycling. Mar Ecol Prog Ser 53:79-91

Hanson RB, Robertson CY (1992) Thymidine incorporation, frequency of dividing cells, and growth rates of bacteria. In: Nagel PA (ed) Results of the third joint US-USSR Bering \& Chukchi Seas Expedition (BERPAC), Summer 1988. US Fish and Wildlife Service, Washington, DC, p $60-74$

Hara S, Terauchi K, Koike I (1991) Abundance of viruses in marine waters: assessment by epifluorescence and transmission electron microscopy. Appl environ Microbiol 57: 2731-2734

Heldal M, Bratbak G (1991) Production and decay of viruses in aquatic environments. Mar Ecol Prog Ser 72:205-212

Hood DW, Calder JA (eds) (1981) The eastern Bering Sea Shelf: oceanography and resources, Vol 2. University of Washington Press, Seattle

Jiang SC, Paul JH (1994) Seasonal and diel abundance of viruses and occurrence of lysogeny/bacteriocinogeny in the marine environment. Mar Ecol Prog Ser 104:163-172

Kanneworff E, Nicolaisen W (1973) The 'Haps', a framesupported bottom corer. Ophelia 10:119-128

Kirchman D, K'Nees E, Hodson R (1985) Leucine incorporation and its potential as a measure of protein synthesis by bacteria in natural aquatic systems. Appl environ Microbiol 49:599-607

Kirchman DL, Suzuki Y, Garside C, Ducklow HW (1991) High turnover rates of dissolved organic carbon during a spring phytoplankton bloom. Nature 352:612-614
Kudryatsev VM, Mamaev VO, Strigunkova TF (1992) Bacterial production and destruction of organic matter. In: Nagel PA (ed) Results of the third joint US-USSR Bering \& Chukchi Seas Expedition (BERPAC), summer 1988. US Fish and Wildlife Service, Washington, DC, p 75-78

Lee S, Fuhrman JA (1987) Relationships between biovolume and biomass of naturally derived marine bacterioplankton. Appl environ Microbiol 53:1298-1303

Maranger R, Bird DF, Juniper SK (1994) Viral and bacterial dynamics in Arctic sea ice during the spring algal bloom near Resolute, NWT, Canada. Mar Ecol Prog Ser 111. $121-127$

McManus GB, Fuhrman JA (1988) Control of marine bacterioplankton populations: measurement and significance of grazing. Hydrobiologia 159:51-62

McRoy PC (1993) ISHTAR, the project: an overview of Inner Shelf Transfer And Recycling in the Bering and Chukchi seas. Cont Shelf Res 13:473-479

Murray AG, Eldridge PM (1994) Marine viral ecology incorporation of bacteriophage into the microbial planktonic food web paradigm. J Plankton Res 16:627-641

Nagel PA (ed) (1992) Results of the third joint US-USSR Bering \& Chukchi Seas expedition (BERPAC), Summer 1988. US Fish and Wildlife Service, Washington, DC

Pace ML (1988) Bacterial mortality and the fate of bacterial production. Hydrobiologia 159:41-49

Paul JH, Rose JB, Jiang SC, Kellogg CA, Dickson L (1993) Distribution of viral abundance in the reef environment of Key Largo, Florida. Appl environ Microbiol 59:718-724

Pomeroy LR, Sheldon. JE, Sheldon WM, Peters F (1995) Limits to growth and respiration of bacterioplankton in the Gulf of Mexico. Mar Ecol Prog Ser 117:259-268

Pomeroy LR, Wiebe WJ, Deibel D, Thompson RJ, Rowe GT, Pakulski JD (1991) Bacterial responses to temperature and substrate concentration during the Newfoundland spring bloom. Mar Ecol Prog Ser 75:143-159

Proctor LM, Fuhrman JA (1990) Viral mortality of marine bacteria and cyanobacteria. Nature 343:60-62

Proctor LM, Fuhrman JA (1991) Roles of viral infection in organic particle flux. Mar Ecol Prog Ser 69:133-142

Proctor LM, Okubo A, Fuhrman JA (1993) Calibrating estimates of phage-induced mortality in marine bacteria: ultrastructural studies of marine bacteriophage development from one-step growth experiments. Microb Ecol 25: 161-182

Sambrotto RN, Goering JJ, McRoy CP (1984) Large yearly production of phytoplankton in the Bering Strait. Science 255:1147-1150

Saye DJ, Ogunseitan OA, Sayler GS, Miller RV (1990) Transduction of linked chromosomal genes between Pseudomonas aeruginosa strains during incubation in situ in a freshwater habitat. Appl environ Microbiol 56:140-145

Simon M, Azam F (1989) Proteln content and protein synthesis rates of planktonic marine bacteria. Mar Ecol Prog Ser 51:201-213

Smith DC, Azam F (1992) A simple, economical method for measuring bacterial protein synthesis rates in seawater using ${ }^{3} \mathrm{H}$-leucine. Mar microb Food Webs 6:107-114

Smith DC, Steward GF, Azam F, Hollibaugh JT (1992) Virus and bacteria abundance in the Drake Passage dunng January and August 1991. Antarct J US 27:125-127

Smith DC, Steward GF, Long RA, Azam F (1995) Bacterial mediation of carbon fluxes during a diatom bloom in a mesocosm. Deep Sea Res II 42:75-97

Springer AM, MCRoy PC (1993) The paradox of pelagic food webs in the northern Bering Sea. III. Patterns of primary production. Cont Shelf Res 13:575-599 
Steward GF, Wikner J, Cochlan WP, Smith DC, Azam F (1992a) Estimation of virus production in the sea: I. Method development. Mar microb Food Webs 6:57-78

Steward GF, Wikner J, Cochlan WP, Smith DC, Azam F (1992b) Estimation of virus production in the sea: II. Field results. Mar microb Food Webs 6:79-90

Strayer D (1988) On the limits to secondary production. Limnol Oceanogr 33:1217-1220

Turley CM, Hughes DJ (1992) Effects of storage on direct estimates of bacterial numbers of preserved seawater samples. Deep Sea Res 39:375-394

Walsh JJ (1989) Arctic carbon sinks: present and future. Global biogeochem Cycles 3:393-411

Walsh JJ, McRoy CP, Coachman LK, Goering JJ, Nihoul JJ, Whitledge TE, Blackburn TH, Parker PL, Wirick CD, Shuert PG, Grebmeier JM, Springer AM, Tripp RD, Hansell DA, Djenidi S, Deleersnijder E, Henriksen K.
Lund BA, Andersen P, Müller-Karger FE, Dean K (1989) Carbon and nitrogen cycling within the Bering/Chukchi Seas: source regions for organic matter effecting $\mathrm{AOU}$ demands of the Arctic Ocean. Prog Oceanogr 22:277-359

Weinbauer MG. Fuks D. Peduzzi. P (1993) Distribution of viruses and dissolved DNA along a coastal trophic gradient. in the northern Adriatic Sea. Appl environ Microbiol 59:4074-4082

Weinbatuer MG, Peduzzi P (1994) Frequency; size and distribution of bacteriophages in different marine bacterial morphotypes. Mar Ecol Prog Ser 108:11-20

Wilcox RM, Fuhrman JA (1994) Bacterial viruses in coastal seawater: lytic rather than lysogenic production. Mar Ecol Prog Ser 114:35-45

Wommack KE, Hill RT, Kessel M, Russek-Cohen E, Colwell R (1992) Distribution of viruses in the Chesapeake Bay. Appl environ Microbiol 58:2965-2970

This article was presented by J. Fuhrman (Senior Editorial Advisor), Los Angeles, California, USA
Manuscript first received: May 19, 1995

Revised version accepted: September 28, 1995 